\title{
The Effect of Corporate Social Responsibility on Bank Efficiency in Developed Countries
}

\author{
Fadli Septianto ${ }^{1}$, Viverita ${ }^{2 *}$. \\ ${ }^{1,2}$ Department of Management, Faculty of Economics and Business, Universitas Indonesia. \\ *Corresponding author. Email: viverita.d@ui.ac.id
}

\begin{abstract}
This study aims to investigate the effect of CSR on bank cost efficiency. Based on an international sample of 87 banks in 20 developed countries over 2005 - 2018 periods, we apply stochastic frontier estimation procedures to compute bank cost efficiency. In the second stage regression, we use Feasible Generalized Least Square (FGLS) to measure the influence of CSR on bank cost efficiency. Our empirical investigation reveals that CSR has a positive significant impact on bank cost efficiency. The investigation also finds that the effect of CSR on bank efficiency become not significant during crisis period. In addition, we find that CSR performance increased during crisis, while the bank efficiency decreased.
\end{abstract}

Keywords: Corporate social responsibility, Cost Efficiency, Bank.

\section{INTRODUCTION}

The application of Corporate Social Responsibility (CSR) in influencing company performance is still a question, especially in the banking industry. This is because the implementation of CSR will undoubtedly take time, effort and costs so that it is contrary to the banking industry, which always demanded to be efficient. In this case, banks are only required to manage stakeholders who have the most influence on the company [1]. Although in several studies, CSR supports long-term company performance improvement [2]. However, the effect of CSR on the banking sector remains debatable.

The effect of CSR on bank profitability were studied by some scholars. For example, EstebanSanchez et al [1] and $\mathrm{Wu}$ and Shen [3] found that there is a positive relation between CSR performance and bank profitability, as measured by financial ratios. However, the use of financial ratios has limitations in explaining bank performance, since it's only a partial measurement and ignore other factors that contribute to profitability. Efficiency is considered as an appropriate measure in explaining bank performance [4] since it considers all relevant determinants of profitability.
Research related to CSR and efficiency conducted by Belasri et al. [5] found that CSR performance has a positive significant effect on bank efficiency. This is explained by the increase in reputation caused by the bank's CSR performance. However, research related to CSR and bank performance is still limited, especially regarding the effect of CSR in influencing bank costefficiency.

After the crisis, several studies conducted to investigate the effect of the financial crisis on bank efficiency. Moreover, many studies performed to test their effect on bank efficiency during a crisis such as diversification and ownership [6]. However, as far as our knowledge, there are no studies that examine the effect of CSR on bank efficiency during times of crisis. One of the arguments underlying this research is that a good CSR performance can build a reputation in maintaining the sustainability and competitiveness of the bank. This phenomenon can be interesting for customers and divert attention from the risks that occur during a crisis [7].

Based on the explanation above, CSR has an essential role in building a long-term reputation that will be able to increase the company's profitability. However, it is still in doubt where the benefits of CSR 
are assessed differently in each industrial sector, especially the banking sector [1]. There is no consensus among researchers regarding the effect of CSR on bank cost efficiency. Therefore, this study will empirically examine the effect of CSR performance on bank efficiency using an international sample.

\section{LITERATURE AND HYPOTHESIS DEVELOPMENT}

\subsection{CSR and Bank Performance}

$C$ SR activities has been widely debated in academic studies in recent years. The focus of the debate is to find out the reason why companies are willing to invest large amounts of resources in CSR activities. There are two views in responding to this phenomenon [8]. The shareholders' view comes from the neoclassical economic theory, which stated that the only responsibility of a company manager is to maximize profits within limits permitted by law. On the other hand, the views of stakeholders indicate that firm's ethical behavior and profits are not mutually exclusive for shareholders. However, they play a role in all stakeholder interests, especially in improving company's performance.

In the numerous of this CSR theoretical debate, several studies have tried to estimate the link between corporate social performance and financial performance empirically. Using international samples, Wu and Shen [3] and Esteban-Sanchez et al. [1] found that banks CSR capabilities has positive impact with their financial performance as proxied by traditional measurements such as return on equity (ROE) and return on asset (ROA).

Beside ROA and ROE, efficiency usually used to measure the banks' performance. A recent study conducted by Belasri et al. [5] found that there is a positive influence of CSR on bank efficiency. More specifically, financial benefits and bank efficiency could be generated by developing CSR capabilities. The research shows that Banks does not waste their resources by spending it to CSR. Otherwise, it leads to a better resources utilization. Therefore, we propose the following hypothesis:

H1. CSR has a positive impact on bank efficiency.

\subsection{CSR, Crisis and Bank Performance}

$\mathrm{Wu}$ and Shen [3] analyzed the impact of CSR on financial performance in the banking industry during the periods of before and after the global financial crisis. They found that CSR had a positive impact on financial performance before the financial crisis (2005 - 2007) but there is no impact on ROA after the crisis (2008 - 2010). They suggested that the crisis negatively affects the impact of CSR on financial performance but only up to certain point. Using French sample firms, Ducassy [9] found a positive relationship corresponding to the start of the crisis; however, this links are not significant after the first semester. However, Bansal et al. [10] found that companies tend to mitigate their tactical CSR (shortterm costs) than the CSR strategy (long-term investment) during a financial crisis. This finding indicated that CSR is more of a strategic decision than a tactical actions to survive a recession since the activities are implemented out regularly.

According to the CSR business case approach, the bank can avoid performance deterioration if they maintain or increases CSR activities during a crisis. As a result, a crisis would have a positive effect on CSR and performance relation. However, some controversies and scandals occur during a crisis. Therefore, CSR policies of banks and their socially responsible behavior have been questioned. The CSR performance failed during the crisis, certainly in corporate governance and product responsibility. In that case, there would be an expectation of a negative interaction effect of the crisis. Therefore, the hypothesis is as follows.

H2. Crisis has a significant influence on CSR-efficiency relationship.

\section{DATA AND METHODOLOGY 3.1 Sample and Data}

This study uses secondary from the banks' balance sheets and income statements as well as environmental, social and governance (ESG) reports in developed countries from 2005 to 2018. The dataset compiled from Thomson Reuters Datastream and Asset4. The number of banks used as samples in the study is 87 banks from 20 countries, consisting of 44 banks from Europe, 24 banks from America, 22 banks from Asia and five banks from Oceania. 


\subsection{Bank Efficiency}

This study uses the Stochastic Frontier Analysis (SFA) to measure bank cost efficiency based on several reasons. First, SFA controls error in its measurement and other random effects. Besides that, the method has widely used in measuring the efficiency of banks and other industries [4]. Cost efficiency quantify how close the bank's actual costs are to the best practice bank's costs in producing the same output under the same inputs.

Based on the SFA model from Battese and Coelli [11], this research measures the level of efficiency by determining the translog cost function. The translog cost function of this study is as follows:

$\ln \left(\frac{T C}{w_{3}}\right)=a+\sum_{i=1}^{4} \beta_{i} \ln Y_{i}+$

$\sum_{k=1} \psi_{i} \ln \left(\frac{W_{k}}{w_{3}}\right)+\frac{1}{2} \sum_{i=1}^{4} \sum_{j=1}^{4} \beta_{i j} \ln Y_{i} \ln Y_{j}+$

$\frac{1}{2} \sum_{k=1} \times$

$\sum_{m=1} \psi_{k m} \ln \left(\frac{W_{k}}{w_{3}}\right) \ln \left(\frac{W_{m}}{w_{3}}\right)+$

$\sum_{i=1}^{4} \sum_{k=1} \phi_{i k} \ln Y_{i} \ln \left(\frac{W_{k}}{w_{3}}\right)+u_{i t}+v_{i t}$

(1)

Following Doan et al. [6], Equation (1) consists the following four outputs (Yi): total loans (Y1), other productive assets (Y2), total deposits (Y3), and liquid assets (Y4). It is also broadly consistent with previous studies on bank efficiency. Equation (1) uses the following three input prices (Wk): capital price (W1), which determined by the ratio of non-interest costs to total fixed assets, fund price (W2) which is determined by the interest expense ratio to total savings, and the price of labour (W3) as measured by the ratio of cost of labour to total assets. Total bank cost (TC) defines as the sum of interest costs and non-interest expenses. Apart from that, linear homogeneity was also imposed by normalizing using the price of labour (W3). We also normalize total cost and output variables with total assets to control for scale bias and heteroscedasticity.

\subsection{ESG Score}

This study gathered CSR data from Asset4 Thomson Reuters database. It is commonly used to resolve the difficulties in measuring CSR, such as materiality and information availability. Several empirical studies use Asset4 for CSR Measurement [1], [12]. ESG rating data is in the form of values in the range 0 to 100 .

\subsection{Model and statistical methods}

The model used in this study follows Belasri et al. [5]. This study used cost efficiency as the dependent variable. The regression model is as follows

$$
\begin{aligned}
& \text { Eff }_{i, t}=\beta_{0}+\beta_{1} \operatorname{CSR}_{i, t}+\beta_{2} \text { Crisis }_{i, t}+\beta_{3} \text { Size }_{i, t}+ \\
& \beta_{4} \operatorname{Lev}_{i, t}+\beta_{5} L D R_{i, t}+\beta_{6} \operatorname{Liq}_{i, t}+\beta_{7} \operatorname{GDPg}_{i, t}+ \\
& \beta_{8} \operatorname{GDPC}_{i, t}+\beta_{9} \operatorname{Inf}_{i, t}
\end{aligned}
$$

Based on Equation (2) Eff is the efficiency score for bank $i$ at time $t$ obtained from SFA model. The first explanatory variables is CSR and crisis. In addition, control variables are also used in this study in the form of bank characteristics and macroeconomic variables. The bank characteristic variables used are Size, Leverage (Lev), Loan Deposit Ratio (LDR), Liquidity (Liq). Meanwhile, the macroeconomic variables used are GDP growth (GDPg), GDP per capita (GDPc) and inflation (Inf). The definition of the variables is explained in Table 1.

Table 1: Variable Definition

\begin{tabular}{|l|l|l|}
\hline Variable & Source & Description \\
\hline Cost Efficiency & $\begin{array}{l}\text { Stochastic } \\
\text { Frontier } \\
\text { Approach }\end{array}$ & Cost Efficiency Score \\
\hline \multicolumn{3}{|c|}{ Independent Variable } \\
\hline CSR & Datastream & $\begin{array}{l}\text { Environmental, Social } \\
\text { and Governance score }\end{array}$ \\
\hline \multicolumn{3}{|c|}{ Bank Characteristics } \\
\hline Size & Datastream & $\begin{array}{l}\text { Natural logarithm of } \\
\text { total assets }\end{array}$ \\
\hline Leverage & Datastream & Equity to total assets \\
\hline $\begin{array}{l}\text { Loan deposit } \\
\text { ratio }\end{array}$ & Datastream & $\begin{array}{l}\text { Total loans to total } \\
\text { deposits }\end{array}$ \\
\hline Liquidity & Datastream & $\begin{array}{l}\text { Liquid assets to total } \\
\text { deposits }\end{array}$ \\
\hline \multicolumn{3}{|c|}{} \\
\hline GDP growth & Worldbank & Annual GDP growth rate \\
\hline GDP per capita & Worldbank & GDP per capita \\
\hline Inflation & Worldbank & Annual inflation rate \\
\hline \multicolumn{3}{|c|}{ Moderating Variables } \\
\hline Crisis & \multicolumn{2}{|c|}{ Dummy for crisis year } \\
\hline
\end{tabular}

This study also examines the effect of CSR on bank efficiency in the time of crisis on Equation (3). Therefore, the interaction model to be estimated is as follows: 
$E f f_{i, c, t}=\beta_{0}+\beta_{1} \operatorname{CSR}_{i, c, t}+\beta_{2} \operatorname{CSR}_{i, c, t} \times \operatorname{Crisis}_{i, c, t}+$ $\beta_{3}$ Crisis $_{i, c, t}+\beta_{4}$ Size $_{i, c, t}+\beta_{5}$ Lev $_{i, c, t}+\beta_{6} L D R_{i, c, t}+$ $\beta_{7} L_{i q_{i, c, t}}+\beta_{8} G D P g_{i, c, t}+\beta_{9} G D P c_{i, c, t}+\beta_{10} I n f_{i, c, t}$

This study uses Feasible Generalized Least Squares (FEGLS) estimation to solve autocorrelation and heteroscedasticity problems. Hausman test is conducted to find out which model is better to use between random or fixed effects. The test results show that the random effect is more accurate in estimation.

\subsection{Discussion}

This section presents the descriptive statistics and estimation results.

Table 2 presents summary statistics of variables used in the study. The cost efficiency, leverage, LDR and liquidity are presented in percentage form. Meanwhile, size and GDP growth use log form in the estimation. The mean value of bank efficiency for all samples is 92,212 , with a minimum value of 41,526 and maximum of 99,313 . This finding indicates that all banks in the sample have a high mean value of efficiency because it closed to the maximum value of 100 . CSR shows a mean value 48,756 , with a minimum value of 3,680 and a maximum value of 90,250 . This result implies that the CSR of all banks shows variety of values.

Table 2: Descriptive Statistic

\begin{tabular}{|l|c|c|c|c|c|}
\hline Variable & Obs & Mean & $\begin{array}{l}\text { Std. } \\
\text { Dev. }\end{array}$ & Min & Max \\
\hline $\begin{array}{l}\text { Cost } \\
\text { Efficienc } \\
\text { y }\end{array}$ & 1,218 & $\begin{array}{c}92.21 \\
2\end{array}$ & 7.589 & 41.52 & 99.313 \\
\hline CSR & 1,218 & $\begin{array}{c}48.75 \\
6\end{array}$ & 20.042 & 3.680 & 90.25 \\
\hline Size & 1,218 & $\begin{array}{c}19.16 \\
6\end{array}$ & 1.325 & 15.92 & 22.130 \\
\hline Leverage & 1,218 & 7.095 & 3.224 & -4.307 & 32.796 \\
\hline LDR & 1,246 & $\begin{array}{c}118.4 \\
0\end{array}$ & 50.539 & 43.40 & 450.56 \\
\hline Liquidity & 1,246 & $\begin{array}{c}16.41 \\
4\end{array}$ & 61.536 & 0.057 & 970.83 \\
\hline $\begin{array}{l}\text { GDP } \\
\text { Capita }\end{array}$ & 1,246 & $\begin{array}{c}10.66 \\
7\end{array}$ & 0.264 & 9.805 & 11.542 \\
\hline $\begin{array}{l}\text { GDP } \\
\text { Growth }\end{array}$ & 1,246 & 0.977 & 2.537 & -8.998 & 23.986 \\
\hline Inflation & 1,246 & 1.569 & 1.392 & -4.478 & 6.628 \\
\hline Crisis & 1,246 & 0.214 & 0.410 & 0.000 & 1 \\
\hline
\end{tabular}

Table 3. Pairwise Correlation Matrix

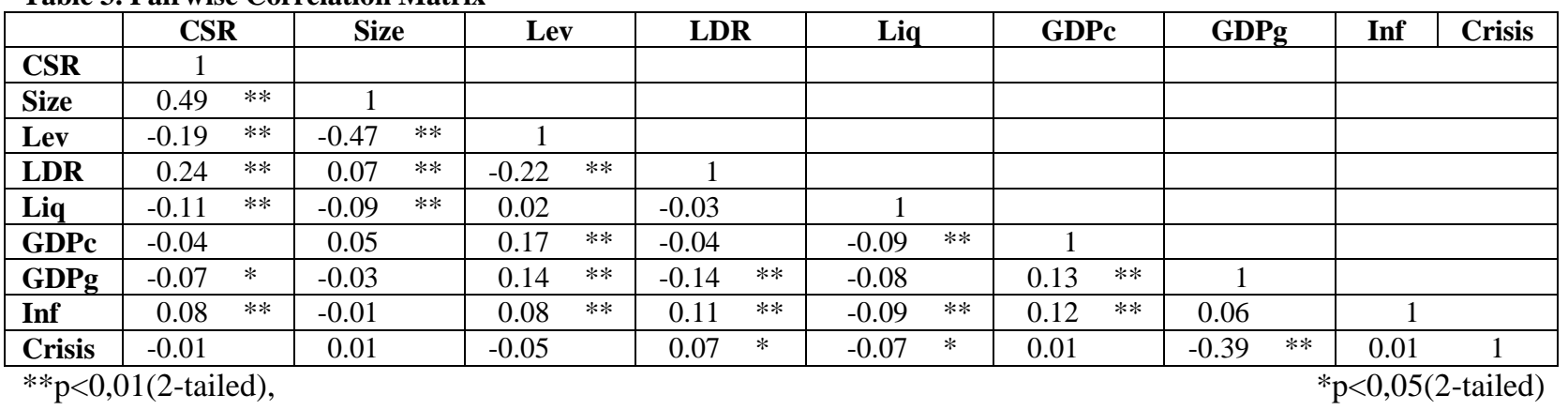

Table 3 shows the correlation coefficient matrix between the independent variables in this study. CSR has a positive and significant correlation to size and LDR. This result shows that banks with large assets tend to have good CSR capabilities. Likewise, banks with large loans tend to have strong CSR performance. CSR has a significant negative correlation with leverage and liquidity. This condition shows that banks with considerable equity and liquid assets tend to have less CSR performance.

Table 4. Summary Statistic of Efficiency and CSR

\begin{tabular}{|l|c|c|l|c|c|}
\hline Result & Efficiency & CSR & \multicolumn{2}{c|}{ Result } & \multicolumn{2}{c|}{ Efficiency } & CSR \\
\hline Full sample mean & 0.922 & 48.75 & \multicolumn{2}{|c|}{ Panel B - means by country } \\
\hline Full sample min & 0.415 & 3.68 & Australia & 0.930 & 65.79 \\
\hline Full sample max & 0.993 & 90.25 & Austria & 0.938 & 46.23 \\
\hline Crisis (2008-2010) & 0.919 & 48.39 & Belgium & 0.933 & 64.87 \\
\hline Before Crisis & 0.924 & 41.110 & Canada & 0.942 & 63.24 \\
\hline After Crisis & 0.923 & 51.759 & Denmark & 0.935 & 32.64 \\
\hline \multicolumn{2}{|l}{} & Finland & 0.929 & 57.32 \\
\hline
\end{tabular}




\begin{tabular}{|l|l|l|l|l|l|}
\hline 2005 & 0.917 & 38.56 & France & 0.874 & 57.60 \\
\hline 2006 & 0.929 & 40.36 & Germany & 0.948 & 51.07 \\
\hline 2007 & 0.925 & 44.41 & Greece & 0.929 & 56.82 \\
\hline 2008 & 0.918 & 47.92 & China & 0.848 & 44.21 \\
\hline 2009 & 0.923 & 48.31 & Ireland & 0.887 & 42.28 \\
\hline 2010 & 0.916 & 48.95 & Italy & 0.920 & 59.88 \\
\hline 2011 & 0.933 & 49.85 & Japan & 0.930 & 32.40 \\
\hline 2012 & 0.927 & 49.85 & Norway & 0.916 & 65.60 \\
\hline 2013 & 0.929 & 48.49 & Portugal & 0.942 & 63.26 \\
\hline 2014 & 0.926 & 49.41 & Singapore & 0.873 & 38.20 \\
\hline 2015 & 0.920 & 53.88 & Spain & 0.929 & 71.08 \\
\hline 2016 & 0.913 & 53.40 & Sweden & 0.934 & 61.50 \\
\hline 2017 & 0.910 & 55.61 & United Kingdom & 0.919 & 51.02 \\
\hline 2018 & 0.924 & 53.58 & United States & 0.932 & 41.92 \\
\hline
\end{tabular}

Table 5. Estimation Result

\begin{tabular}{|c|c|c|c|c|}
\hline \multirow{3}{*}{$\begin{array}{l}\text { Variable } \\
\text { CSR } \\
\end{array}$} & \multicolumn{4}{|c|}{ Cost Efficiency } \\
\hline & \multicolumn{2}{|l|}{ (1) } & \multicolumn{2}{|c|}{ (2) } \\
\hline & 0.0181 & $* *$ & 0.0206 & $* *$ \\
\hline & $(0.0083)$ & & $(0.0085)$ & \\
\hline \multirow[t]{2}{*}{ Crisis } & -0.8036 & $* * *$ & -0.0818 & \\
\hline & $(0.2385)$ & & $(0.5625)$ & \\
\hline \multirow[t]{2}{*}{ CSR $x$ Crisis } & & & -0.0150 & \\
\hline & & & $(0.0106)$ & \\
\hline \multirow[t]{2}{*}{ Size } & 0.0231 & & 0.0293 & \\
\hline & $(0.1831)$ & & $(0.1832)$ & \\
\hline \multirow[t]{2}{*}{ Leverage } & 0.0709 & & 0.0712 & \\
\hline & $(0.0625)$ & & $(0.0624)$ & \\
\hline \multirow[t]{2}{*}{ LDR } & -0.0103 & $* *$ & -0.0102 & $* *$ \\
\hline & $(0.0047)$ & & $(0.0047)$ & \\
\hline \multirow[t]{2}{*}{ Liquidity } & 0.0004 & & 0.0005 & \\
\hline & $(0.0016)$ & & $(0.0016)$ & \\
\hline \multirow[t]{2}{*}{ GDP per Capita } & 1.2528 & $*$ & 1.2283 & \\
\hline & $(0.7477)$ & & $(0.7482)$ & \\
\hline \multirow[t]{2}{*}{ GDP Growth } & -0.0900 & $* *$ & -0.0905 & $* *$ \\
\hline & $(0.0351)$ & & $(0.0349)$ & \\
\hline \multirow[t]{2}{*}{ Inflation } & -0.0153 & & -0.0170 & \\
\hline & $(0.0695)$ & & $(0.0694)$ & \\
\hline \multirow[t]{2}{*}{ Constant } & 80.2714 & $* * *$ & 80.2819 & $* * *$ \\
\hline & $(8.2885)$ & & $(8.2881)$ & \\
\hline Observation & 1218 & & 1218 & \\
\hline Wald chi2 & 30.76 & $* * *$ & 32.89 & $* * *$ \\
\hline
\end{tabular}

The finding also indicates that banks with high leverage and liquidity capabilities do not pay much attention to CSR as company protectors. In contrast, banks with high loans tend to use their reputation generated by CSR performance to protect companies from adverse effects when non-performing loans rise.

Table 4 shows a summary of the efficiency and CSR scores. Panel A shows the mean score by year. The year with the highest average efficiency score was 2011, and the CSR score was 2017. While the year with the lowest mean efficiency score is 2017 and the CSR score is 2005. Moreover, in the crisis period, the average efficiency and CSR score were 0.919 and 48.39. These values are lower than that of the value after the crisis, which is 0.923 and 48.85 . Table 4 Panel B shows the mean score by country. The country with the highest mean efficiency score is Germany, and the CSR score is Spain. Meanwhile, the country with the lowest mean efficiency score is China, and the lowest CSR score is Japan.

Table 5 shows the results of the empirical model estimation. First, column (1) presents the effect of CSR and bank cost efficiency in order to answer hypothesis 1. Meanwhile, column (2) shows the result of the model estimation to include the effect of CSR on bank cost efficiency during the crisis. Table 5 shows that CSR has a positive and significant effect on bank cost efficiency. This result is consistent with a previous study [1], [3], [5]. Banks with better CSR can increase their cost-efficiency. It explains that maintaining good relations with stakeholders result in higher competitive advantage [8]. Thus, the good relationship can improve the company's reputation, productivity and loyalty of the employee, and the ability to maintain product prices [5]. In this case, 
banks with good CSR capabilities can increase efficiency by reducing the cost of inputs used [3].

The crisis variable has a significant and negative effect on bank cost efficiency. This finding is consistent with previous study [1]. This result indicates that the global financial crisis has caused a significant reduction in bank cost efficiency in developed countries.

LDR and GDP growth have a negative and significant impact on bank efficiency. This result contradicts previous study [5]. However, this result partially promotes the view that high economic growth increases the business environment and reduces bank entry barriers. Consequently, improved competition dampens banks' profitability [13]. Meanwhile, the increases of LDR also increase the liquidity buffer, which had an impact on the declining of bank efficiency indicate that unproductive funds increased [14].

Furthermore, this study finds a negative effect of CSR on bank cost efficiency during the crisis. However, the effect is not significant. Thus, this study fails to reject hypothesis 2. This finding is consistent with a previous study by Ducassy [9]. The result shows that the role of CSR does not reduce the negative effect of the crisis. This result shows that CSR activities can not divert customer attention from the risks that occur during the crisis [7]. The result also indicates that CSR activities that perform by the bank are more tactical than a strategic decision. As a result, a bank with tactical CSR only even more produce a temporary buffer when facing the period of uncertainty [10].

\section{CONCLUSION}

This study aims to investigate the effect of CSR on bank cost efficiency in developed countries. Besides, this study also examines the effect of the crisis on the relation between CSR and bank cost efficiency.

Results of this study indicate that strong bank CSR capabilities will increase cost-efficiency. This finding indicates that banks need to manage good relations with all stakeholders. Bank spending on CSR capabilities improvement will generate benefit. However, when it comes to a crisis, CSR performance becomes irrelevant for cost efficiency.
This research is not without flaws and limitations. This study only focuses on measuring CSR as a whole compared to specific measurements. Furthermore, due to data limitations, this study only investigates banks in developed countries. It will be beneficial if we compare the CSR capability between banks in the developed and emerging market to recognize the different behavior of bank in complying with CSR regulation.

\section{REFERENCES}

[1] P. Esteban-Sanchez, M. de la CuestaGonzalez, and J. D. Paredes-Gazquez, "Corporate social performance and its relation with corporate financial performance: International evidence in the banking industry," J. Clean. Prod., 2017, doi: 10.1016/j.jclepro.2017.06.127.

[2] H. C. Yu, L. Kuo, and M. F. Kao, "The relationship between CSR disclosure and competitive advantage," Sustain. Accounting, Manag. Policy J., 2017, doi: 10.1108/SAMPJ-11-2016-0086.

[3] M. W. Wu and C. H. Shen, "Corporate social responsibility in the banking industry: Motives and financial performance," J. Bank. Financ., 2013, doi: 10.1016/j.jbankfin.2013.04.023.

[4] S. C. Kumbhakar and C. A. K. Lovell, Stochastic Frontier Analysis. 2000.

[5] S. Belasri, M. Gomes, and G. Pijourlet, "Corporate social responsibility and bank efficiency," J. Multinatl. Financ. Manag., 2020, doi: 10.1016/j.mulfin.2020.100612.

[6] A. T. Doan, K. L. Lin, and S. C. Doong, "What drives bank efficiency? The interaction of bank income diversification and ownership," Int. Rev. Econ. Financ., 2018, doi: 10.1016/j.iref.2017.07.019.

[7] N. Gambetta, M. A. García-Benau, and A. Zorio-Grima, "Corporate social responsibility and bank risk profile: evidence from Europe," Serv. Bus., 2017, doi: 10.1007/s11628-016-0318-1.

[8] M. E. Porter and M. R. Kramer, "Strategy \& society: The link between competitive advantage and corporate social responsibility," Harv. Bus. Rev., 2006, doi: 10.1108/sd.2007.05623ead.006. 
[9] I. Ducassy, "Does Corporate Social Responsibility Pay Off in Times of Crisis? An Alternate Perspective on the Relationship between Financial and Corporate Social Performance," Corp. Soc. Responsib. Environ. Manag., 2013, doi: $10.1002 / \mathrm{csr} .1282$.

[10] P. Bansal, G. F. Jiang, and J. C. Jung, "Managing responsibly in tough economic times: Strategic and tactical CSR during the 2008-2009 global recession," Long Range Plann., 2015, doi: 10.1016/j.lrp.2014.07.002.

[11] G. E. Battese and T. J. Coelli, "A model for technical inefficiency effects in a stochastic frontier production function for panel data," Empir. Econ., 1995, doi: 10.1007/BF01205442.
[12] M. del M. Miras-Rodríguez, A. CarrascoGallego, and B. Escobar-Pérez, "Has the CSR engagement of electrical companies had an effect on their performance? A closer look at the environment," Bus. Strateg. Environ., 2015, doi: 10.1002/bse. 1848 .

[13] Y. Tan and C. Floros, "Bank profitability and GDP growth in China: A note," J. Chinese Econ. Bus. Stud., 2012, doi: 10.1080/14765284.2012.703541.

[14] A. W. Widiarti, H. Siregar, and T. Andati, "THE DETERMINANTS OF BANK'S EFFICIENCY IN INDONESIA," Bul. Ekon. Monet. dan Perbank., 2015, doi: 10.21098/bemp.v18i2.520. 